\title{
Faktor-Faktor yang Mempengaruhi Tax Avoidance
}

\author{
Anis Susilowati ${ }^{1}$, Riana Rahmawati Dewi ${ }^{2}$, Anita Wijayanti ${ }^{3}$ \\ 1,2,3 Universitas Islam Batik, JL. KH. Agus Salim No. 10, Surakarta, Indonesia \\ Correspondence email: anissusilowati99@gmail.com
}

\begin{abstract}
Abstrak. Penelitian ini bertujuan untuk mengetahui pengaruh ukuran perusahaan, leverage, profitabilitas, pertumbuhan penjualan, komite audit dan arus kas operasi terhadap tax avoidance. Variabel dependen dalam penelitian ini yaitu tax avoidance sedangkan variabel independen yang digunakan dalam penelitian ini yaitu ukuran perusahaaan, leverage, profitabilitas dan komite audit. Penelitian ini difokuskan pada Perusahaan LQ45 yang terdaftar di Bursa Efek Indonesia (BEI) Periode $2015-2018$. Pemilihan sampel dalam penelitian ini menggunakan metode purposive sampling, sehingga diperoleh sampel sebanyak 51 data sampel dari populasi perusahaan LQ45 yang terdaftar di Bursa Efek Indonesia (BEI) periode 2015-2018. Alat analisis yang digunakan dalam penelitian ini adalah analisis regresi linear berganda. Hasil penelitian ini menunjukkan bahwa variabel arus kas operasi berpengaruh terhadap tax avoidance, sedangkan variabel ukuran perusahaan, leverage, profitabilitas, pertumbuhan penjualan dan komite audit tidak berpengaruh terhadap tax avoidance.
\end{abstract}

Kata kunci: Arus Kas Operasi; GCG; Rasio Keuangan; Ukuran Perusahaan;Tax Avoidance

Abstract. The research aims to determine the influence of company size, leverage, profitability, sales growth, audit committee, and cash flow operations against tax avoidance. Dependent variables in this study are tax avoidance while the independent variables used in this research are company size, leverage, profitability and audit committees. This research is focused on the LQ45 company listed on the Indonesia Stock Exchange (IDX) period 2015-2018. The selection of samples in this study used the purposive sampling method, thus obtained a sample of 51 sample data from the LQ45 company population listed on the Indonesia Stock Exchange (IDX) period 2015-2018. The analytical tools used in this study are multiple linear regression analyses. The results of this research show that the variable cash flow operations affect the tax avoidance, while the company size variables, leverage, profitability, sales growth and audit committees do not affect the tax avoidance.

Keywords: Operating cash flow;GCG;Financial Ratio; Company Size;Tax avoidance

\section{PENDAHULUAN}

Pajak mempunyai peranan yang sangat penting dalam kehidupan bernegara, khususnya di dalam pelaksanaan pembangunan karena pajak merupakan sumber pendapatan negara untuk membiayai semua pengeluaran termasuk pengeluaran pembangunan. Pengertian pajak menurut undang-undang No. 28 Tahun 2007 tentang perpajakan, "pajak merupakan kontribusi wajib kepada negara yang terutang oleh orang pribadi atau badan yang bersifat memaksa berdasarkan undangundang, dengan tidak mendapatkan imbalan secara langsung dengan digunakan untuk keperluan negara bagi sebesar-besarnya kemakmuran rakyat". Pembayaran pajak merupakan perwujudan dari kewajiban kenegaraan dan peran serta wajib pajak untuk secara langsung dan bersama-sama melaksanakan kewajiban perpajakan untuk pembiayaan negara dan pembangunan nasional. Sesuai falsafah undang-undang perpajakan, membayar pajak bukan hanya merupakan kewajiban, tetapi merupakan hak dari setiap warga negara untuk ikut berpartisipasi dalam bentuk peran serta terhadap pembiayaan negara dan pembangunan nasional. Tanggung jawab atas kewajiban pembayaran pajak, sebagai pencerminan kewajiban kenegaraan di bidang perpajakan berada pada anggota masyarakat sendiri untuk memenuhi kewajiaban tersebut. Hal tersebut sesuai dengan sistem self assessment yang dianut dalam sistem perpajakan indonesia. Pemerintah dalam hal ini direktorat jendral pajak, sesuai dengan fungsinya berkewajiban melakukan pembinaan/penyuluhan, pelayanan, dan pengawasan.

Suatu perusahaan mungkin saja melakukan tindakan-tindakan untuk menekan beban pajak dengan berbagai faktor, dalam hal ini disatu sisi menguntungkan bagi perusahaan tetapi disisi lain dapat merugikan negara. Tujuan pemerintah untuk memaksimalkan penerimaan dari sektor pajak tersebut bertentangan dengan tujuan perusahaan, dimana perusahaan berusaha meminimalkan beban pajak sehingga memperoleh laba yang lebih besar. Tax avoidance merupakan suatu cara untuk menekan beban pajak yang ditanggung perusahaan secara legal yang tidak melanggar peraturan perpajakan karena dalam peraturan perpajakan diperbolehkan adanya tax avoidance. Dengan diperbolehkan adanya tax avoidance maka banyak yang memanfaatkan celah ini untuk mengurangi beban yang ditangguhkan pada wajib pajak orang pribadi atau badan.

Penelitian yang dilakukan oleh (Dewinta \& Setiawan, 2016) mengatakan bahwa dari hasil penelitiannya ukuran perusahaaan berpengaruh positif terhadap tax avoidance. Begitu juga dengan penelitian dari (Kim \& Im, 2017), (Asri \& Suardana, 2016) mengatakan bahwa ukuran perusahaan berpengaruh terhadap tax avoidance. Akan tetapi berbeda dengan penelitian yang dilakukan oleh (Almaidah, Titisari, \& Nurlaela, 2017), (Permata, Nurlaela, \& Masitoh, 2018) 
dan (Nugraheni \& Pratomo, 2018) mengatakan bahwa ukuran perusahaan tidak berpengaruh terhadap tax avoidance.

Penelitian yang dilakukan oleh (Kim \& Im, 2017) mengatakan bahwa dari hasil penelitiannya leverage berpengaruh terhadap tax avoidance. Begitu juga dengan penelitian dari (Ardianti, 2019), (kusufiyah \& Anggraini, 2019) dan (Praditasari \& Setiawan, 2017) mengatakan bahwa leverage berpengaruh negatif terhadap tax avoidance. Akan tetapi berbeda dengan penelitian yang dilakukan oleh (Dewinta \& Setiawan, 2016) dan (Arianandini \& Ramantha, 2018) mengatakan bahwa leverage tidak berpengaruh terhadap tax avoidance.

Penelitian yang dilakukan oleh (Dewinta \& Setiawan, 2016) mengatakan bahwa dari hasil penelitiannya profitabilitas berpengaruh terhadap tax avoidance. Hal yang sma dilakukan oleh (Kim \& Im, 2017) mengatakan bahwa profitabilitas berpengaruh terhadap tax avoidance. Penelitian oleh (Oktamawati, 2017) mengatakan bahwa profitabilitas berpengaruh terhadap tax avoidance. Akan tetapi berbeda dengan penelitian yang dilakukan oleh (Ardianti, 2019), (Anouar \& Houria, 2017) dan (Permata, Nurlaela, \& Masitoh, 2018) mengatakan bahwa profitabilitas tidak berpengaruh terhadap tax avoidance.

Penelitian yang dilakukan oleh (Dewinta \& Setiawan, 2016) mengatakan bahwa hasil dari penelitiannya pertumbuhan penjualan berpengaruh positif terhadap tax avoidance. Penelitian yang dilakukan oleh (Oktamawati, 2017) mengatakan bahwa pertumbuhan penjualan berpengaruh negatif terhadap tax avoidance. Berbeda dengan penelitian yang dilakukan oleh (Almaidah, Titisari, \& Nurlaela, 2017) dan (Permata, Nurlaela, \& Masitoh, 2018) mengatakan bahwa pertumbuhan penjualan tidak berpengaruh terhadap tax avoidance.

Penelitian yang dilakukan oleh (Mulyani, Wijayanti, \& Masitoh, 2018) mengatakan bahwa dari hasil penelitiannya komite audit berpengaruh terhadap tax avoidance. Begitu juga dengan penelitian dari (Putri, 2018) dan (Nugraheni \& Pratomo, 2018) mengatakan bahwa komite audit berpengaruh terhadap tax avoidance. Akan tetapi berbeda dengan penelitian yang dilakukan oleh (Oktamawati, 2017), (Ardianti, 2019) dan (Almaidah, Titisari, \& Nurlaela, 2017) mengatakan bahwa komite audit tidak berpengaruh terhadap tax avoidance.

Penelitian yang dilakukan oleh (Kim \& Im, 2017) mengatakan bahwa hasil dari penelitiannya arus kas operasi berpengaruh terhadap tax avoidance. Penelitian dalam pemakaian variabel arus kas operasi terhadap tax avoidance belum terdapat diindonesia, maka dari itu penulis akan meneliti variabel arus kas operasi terhadap tax avoidance pada perusahaan LQ45 yang terdaftar di Bursa Efek Indonesia (BEI). Penelitian menggunakan variabel arus kas operasi tersebut untuk mengetahui pengaruh arus kas operasi terhadap tax avoidance pada perusahaan LQ45 yang terdaftar di Bursa Efek Indonesia periode 2015-2018.

Dengan adanya latar belakang masalah dan Gap research tersebut peneliti melakukan pengujian kembali untuk mengetahui dan menganalisis faktor-faktor apa saja yang mempengaruhi tax avoidance. Variabel dependen dalam penelitian ini yaitu tax avoidance dan variabel independen dalam penelitian ini yaitu ukuran perusahaan, leverage, profitabilitas, pertumbuhan penjualan, komite audit dan arus kas operasi. Sampel penelitian ini menggunakan perusahaan LQ45 yang terdaftar di Bursa Efek Indonesia tahun 2015-2018. Berdasarkan latar belakang masalah diatas, maka peneliti tertarik untuk melakukan penelitian dengan judul “ Faktor-Faktor Yang Mempengaruhi Tax Avoidance (Studi Empiris Pada Perusahaan LQ45 Yang Terdaftar di Bursa Efek Indonesia Tahun 2015-2018)" Variabel dependen dalam penelitian yaitu tax avoidance. Variabel independen dalam peneliti ini yaitu ukuran perusahaan, leverage, profitabilitas, pertumbuhan penjualan, komite audit dan arus kas operasi.

\section{METODE}

Pengujian dalam penelitian ini menggunakan alat analisis model regresi linear berganda. Penelitian ini bertujuan untuk mengetahui pengaruh ukuran perusahaan, leverage, profitabilitas, pertumbuhana penjualan, komite audit dan arus kas operasi terhadap tax avoidance. Penelitian ini bersifat kuantitatif yang menekankan analisisnya pada data-data numerikal (angka) dan data sekunder yang diperoleh dari perusahaan LQ45 yang terdaftar di Bursa Efek Indonesia periode 2015-2018.

\section{HASIL DAN PEMBAHASAN Hasil \\ Hasil Uji Regresi Linear Berganda}

Tabel 1. Hasil Uji Regresi Linear Berganda

\begin{tabular}{cc}
\hline Model & $\mathrm{B}$ \\
\hline (constant) & .295 \\
Ukuran perusahaan & .001 \\
Leverage & -.007 \\
Profitabilitas & -.080 \\
Pertumbuhan penjualan & -.001 \\
Komite audit & -.009 \\
Arus kas operasi & -.004 \\
\hline
\end{tabular}

Hasil analisis regresi diperoleh persamaan regresi linear berganda dengan 6 variabel independen sebagai berikut:

$$
\begin{aligned}
& Y^{\prime}=a+b_{1} X_{1}+b_{2} X_{2}+b_{3} X_{3}+b_{4} X_{4}+b_{5} X_{5}+b_{6} X_{6}+e \\
& Y=0,295+0,001-0,007-0,080-0,01-0,009-0,004
\end{aligned}
$$

Apabila nilai konstanta sebesar 0,295 artinya jika ukuran perusahaan, leverage, profitabilitas, pertumbuhan penjulan, komite audit dan arus kas operasi nilainya 
adalah 0 (nol), maka tax avoidance nilainya 0,295. Nilai koefisien ukuran perusahaan bernilai positif aitu 0,001 artinya bahwa setiap peningkatan ukuran perusahaan sebesar 1 satuan, maka akan meningkatkan tax avoidance sebesar 0,001 satuan dengan asumsi variabel independen lainnya tetap. Nilai koefisien leverage bernilai negatif yaitu $-0,007$ artinya bahwa setiap penurunan leverage sebesar 1 satuan, maka akan menurunkan tax avoidance sebesar -0,007 satuan dengan asumsi variabel independen lainnya tetap. Nilai koefisien profitabilitas bernilai negatif yaitu -0.080 artinya bahwa setiap penurunan profitabilitas sebesar 1 satuan, maka akan menurunkan tax avoidance sebesar 0.080 satuan dengan asumsi variabel independen lainnya tetap. Nilai koefisien pertumbuhan penjualan bernilai negatif yaitu -0.001 artinya bahwa setiap penurunan pertumbuhan penjualan sebesar 1 satuan, maka akan menurunkan tax avoidance sebesar -0.001 satuan dengan asumsi variabel independen lainnya tetap. Nilai koefisien komite audit bernilai negatif yaitu -0,009 artinya bahwa setiap penurunan komite audit sebesar 1 satuan, maka akan menurunkan tax avoidance sebesar 0,009 satuan dengan asumsi variabel independen lainnya tetap. Nilai koefisien arus kas operasi bernilai positif aitu $-0,004$ artinya bahwa setiap penurunan arus kas operasi sebesar 1 satuan, maka akan menurunkan tax avoidance sebesar -0,004 satuan dengan asumsi variabel independen lainnya tetap.

\section{Hasil Uji Kelayakan Model (Uji F)}

Tabel 2. Hasil Uji Kelayakan Model (Uji F)

\begin{tabular}{lllll}
\hline $\mathrm{F}_{\text {hitung }}$ & $\mathrm{F}_{\text {tabel }}$ & $\mathrm{Sig}$ & $\mathrm{Stdr}$ & Kesimpulan \\
\hline 3.795 & 2.313 & 0.004 & 0.05 & Model Layak \\
\hline
\end{tabular}

Berdasarkan tabel 2 menunjukkan bahwa $\mathrm{F}$ hitung $>\mathrm{F}$ tabel $(3.795>2.313)$ dan nilai sig $<0,005$ $(0,004<0,05)$ maka dapat disimpulkan bahwa model layak untuk digunakan.

\section{Hasil Uji Hipotesis (Uji t)}

Tabel 3. Hasil Uji Hipotesisi (Uji t)

\begin{tabular}{|c|c|c|c|c|}
\hline Hipotesis & t hitung & t tabel & Sig. & Keterangan \\
\hline $\begin{array}{l}\text { Ukuran } \\
\text { perusahaan }\end{array}$ & .528 & 2.015 & 0.600 & Ditolak \\
\hline Leverage & -1.745 & -2.015 & 0.88 & Ditolak \\
\hline Profitabilitas & -1.447 & -2.015 & 0.155 & Ditolak \\
\hline $\begin{array}{l}\text { Pertumbuhan } \\
\text { penjualan }\end{array}$ & -.338 & -2.015 & 0.737 & Ditolak \\
\hline Komite audit & -1.262 & -2.015 & 0.213 & Ditolak \\
\hline Arus kas operasi & -3.980 & -2.015 & 0.000 & Diterima \\
\hline
\end{tabular}

Berdasrkan tabel 3 menunjukkan variabel ukuran perusahaan memiliki nilai $\mathrm{t}$ tabel sebesar 0.528 dengan nilai signifikansi sebesar 0.600 . Hal ini menunjukkan $t$ tabel lebih kecil dari pada t hitung dan nilai signifikansi lebih besar dari 0.05 artinya ukuran perusahaan ditolak.
Sehingga dapat disimpulkan bahwa ukuran perusahaan tidak berpengaruh terhadap tax avoidance.

Variabel leverage memiliki nilai t tabel sebesar 1.745 dengan nilai signifikansi sebesar 0.88 . Hal ini meunjukkan $t$ tabel lebih kecil dari pada t hitung dan nilai signifikansi lebih besar dari 0.05 artinya leverage ditolak. Sehingga dapat disimpulkan bahwa leverage tidak berpengaruh terhadap tax avoidance.

variabel profitabilitas memiliki nilai $\mathrm{t}$ tabel sebesar -1.447 dengan nilai signifikansi sebesar 0.155 . Hal ini meunjukkan $t$ tabel lebih kecil dari pada t hitung dan nilai signifikansi lebih besar dari 0.05 artinya profitabilitas ditolak. Sehingga dapat disimpulkan bahwa profitabilitas tidak berpengaruh terhadap tax avoidance.

Variabel pertumbuhan penjualan memiliki nilai $\mathrm{t}$ tabel sebesar -0.338 dengan nilai signifikansi sebesar 0.737. Hal ini meunjukkan $t$ tabel lebih kecil dari pada $t$ hitung dan nilai signifikansi lebih besar dari 0.05 artinya pertumbuhan penjualan ditolak. Sehingga dapat disimpulkan bahwa pertumbuhan penjualan tidak berpengaruh terhadap tax avoidance.

Variabel komite audit memiliki nilai $\mathrm{t}$ tabel sebesar -1.262 dengan nilai signifikansi sebesar 0.213. Hal ini meunjukkan $t$ tabel lebih kecil dari pada thitung dan nilai signifikansi lebih besar dari 0.05 artinya komite audit ditolak. Sehingga dapat disimpulkan bahwa komite audit tidak berpengaruh terhadap tax avoidance.

Variabel arus kas operasi memiliki nilai t tabel sebesar -3.980 dengan nilai signifikansi sebesar 0.000 . Hal ini meunjukkan $t$ tabel lebih besar dari pada t hitung dan nilai signifikansi lebih kecil dari 0.05 artinya arus kas operasi diterima. Sehingga dapat disimpulkan bahwa arus kas operasi berpengaruh terhadap tax avoidance.

\section{Hasil Uji Determinasi}

Tabel 4. Hasil Uji Koefisien Determinasi

\begin{tabular}{ccl}
\hline Model & $\begin{array}{c}\text { Adjusted } R \\
\text { Square }\end{array}$ & \multicolumn{2}{c}{ Kesimpulan } \\
\hline 1 & 0.251 & Ukuran perusahaan, leverage, \\
profitabilitas, pertumbuhan & penjualan, komite audit dan arus \\
& & kas operasi secara simultan \\
& & berpengaruh terhadap tax \\
& & avoidance sebesar 25.1\%. \\
\hline
\end{tabular}

Menunjukkan nilai Adjusted $R$ square sebesar 0,251 artinya sumbangan pengaruh ukuran perusahaan, leverage, profitabilitas, pertumbuhan penjualan, komite audit dan arus kas operasi secara simultan berpengaruh terhadap tax avoidance sebesar 25.1\%. Sedangkan sisanya yaitu $74.9 \%$ dijelaskan oleh variabel lain, diluar variabel ukuran perusahaan, leverage, profitabilitas, pertumbuhan penjualan, komite audit dan arus kas operasi. 


\section{Pembahasan}

Berdasarkan pengujian yang telah dilakukan dengan beberapa hipotesis, Penelitian ini menguji pengaruh ukuran perusahaan, leverage, profitabilitas, pertumbuhan penjualan, komite audit dan arus kas operasi terhadap tax avoidance. Berikut ini adalah hasil dari pengujian yang telah dilakukan dalam penelitian ini, dapat dikemukakan sebagai berikut :

\section{Pengaruh ukuran perusahaan terhadap tax avoidance}

Berdasarkan hasil pengujian hipotesis (uji t) yang dilakukan menunjukkan bahwa ukuran perusahaan tidak berpengaruh terhadap tax avoidance. Penelitian ini sejalan dengan penelitian yang dilakukan oleh (Almaidah, Titisari, \& Nurlaela, 2017), (Permata, Nurlaela, \& Masitoh, 2018) dan (Nugraheni \& Pratomo, 2018) mengatakan bahwa ukuran perusahaan tidak berpengaruh terhadap tax avoidance. Tetapi berbanding terbalik dengan penelitian yang dilakukan oleh (Dewinta \& Setiawan, 2016), (Asri \& Suardana, 2016) dan (Kim \& Im, 2017) mengatakan bahwa ukuran perusahaan berpengaruh terhadap tax avoidance.

Besar kecilnya suatu perusahaan tidak berpengaruh pada tax avoidance. Hal ini dikarenakan perusahaan patuh terhadap peraturan perpajakan, perusahaan tidak ingin mengambil resiko dengan dikenakan sanksi yang berdampak pada buruknya citra perusahaan.

\section{Rasio Keuangan}

\section{Pengaruh leverage terhadap tax avoidance}

Berdasarkan hasil pengujian hipotesis (uji t) yang dilakukan menunjukkan bahwa leverage tidak berpengaruh terhadap tax avoidance. Penelitian ini sejalan dengan penelitian yang dilakukan oleh (Dewinta \& Setiawan, 2016) dan (Arianandini \& Ramantha, 2018) mengatakan bahwa leverage tidak berpengaruh. Tetapi berbanding terbalik dengan penelitian yang dilakukan oleh (Praditasari \& Setiawan, 2017), (Kim \& Im, 2017), (Ardianti, 2019) dan (kusufiyah \& Anggraini, 2019) mengatakn bahwa leverage berpengaruh terhadap tax avoidance.

Semakin tinggi tingkat hutang pada suatu perusahaan tidak mempengaruhi terjadinya tax avoidance, hal ini dikarenakan perusahaan dengan tingkat leverage yang tinggi memiliki beban bunga yang tinggi serta resiko yang tinggi pula, jika banyak menggunakan hutang dari pihak luar perusahaan laba perusahaan menjadi tidak optimal. Penggunaan hutang dalam jumlah yang besar juga akan mengakibatkan kerugian pada perusahaan.

\section{Pengaruh profitabilitas terhadap tax avoidance}

Berdasarkan hasil pengujian hipotesis (uji t) yang dilakukan menunjukkan bahwa profitabilitas tidak berpengaruh terhadap tax avoidance. Penelitian ini sejalan dengan penelitian yang dilakukan oleh (Ardianti,
2019), (Anouar \& Houria, 2017) dan (Permata, Nurlaela, \& Masitoh, 2018) mengatakan bahwa profitabilitas tidak berpengaruh terhadap tax avoidance. Tetapi berbanding terbalik dengan penelitian yang dilakukan oleh (Dewinta \& Setiawan, 2016), (Oktamawati, 2017) dan (Kim \& Im, 2017) mengatakan bahwa profitabilitas berpengaruh terhadap tax avoidance.

Perusahaan dengan profitabilitas yang tinggi berarti perusahaan dapat memanfaatkan asetnya secara efektif dan efisien sehingga perusahaan mampu membayar beban pajak yang ditangguhkan. Sehingga dapat disimpulkan bahwa perusahaan dengan tingkat profitabilitas yang tinggi lebih memilih membayar beban pajak yang ditangguhkan dari pada melakukan tax avoidance dengan memanfaatkan celah peraturan perpajakan yang berlaku.

\section{Pengaruh pertumbuhan penjualan terhadap tax avoidance}

Berdasarkan hasil pengujian hipotesis (uji t) yang dilakukan menunjukkan bahwa pertumbuhan penjualan tidak berpengaruh terhadap tax avoidance. Penelitian ini tidak sejalan dengan penelitian yang dilakukan oleh (Dewinta \& Setiawan, 2016) dan (Oktamawati, 2017) mengatakan bahwa pertumbuhan penjualan berpengaruh terhadap tax avoidance. Penelitian ini sejalan dengan penelitian yang dilakukan oleh (Almaidah, Titisari, \& Nurlaela, 2017) dan (Permata, Nurlaela, \& Masitoh, 2018) mengatakan bahwa pertumbuhan penjualan tidak berpengaruh terhadap tax avoidance.

Tingginya tingkat pertumbuhan penjualan suatu perusahaan tidak mempengaruhi tax avoidance. Pertumbuhan penjualan dapat menggambarkan baik buruknya tingkat pertumbuhan penjualan dalam perusahaan dan dalam baik buruknya tingkat pertumbuhan penjualan tersebut bisa dilihat dari seberapa besar profit yang diperoleh dari besarnya pertumbuhan penjualan perusahaan tersebut. Hal ini terjadi karena seiring dengan meningkatnya pertumbuhan penjualan maka perusahaan mampu untuk membayar pajak yang ditangguhkan perusahaan. Sehingga perusahaan cenderung tidak melakukan tax avoidance.

\section{Good Corporate Governance (GCG) \\ Pengaruh komite audit terhadap tax avoidance}

Berdasarkan hasil pengujian hipotesis (uji t) yang dilakukan menunjukkan bahwa komite audit tidak berpengaruh terhadap tax avoidance. Penelitian ini sejalan dengan penelitian yang dilakukan oleh (Almaidah, Titisari, \& Nurlaela, 2017), (Oktamawati, 2017) dan (Ardianti, 2019) mengatakan bahwa komite audit tidak berpengaruh terhadap tax avoidance. Tetapi berbanding terbalik dengan penelitian yang dilakukan oleh (Putri, 2018), (Mulyani, Wijayanti, \& Masitoh, 2018) dan (Nugraheni \& Pratomo, 2018) mengatakan bahwa komite audit berpengaruh terhadap tax avoidance. 
Dengan komite audit sedikit lebih efisien tetapi terdapat kelemahan ide yang dimiliki lebih sedikit, dengan adanya komite yang banyak juga terdapat kelemahan yaitu banyak konflik yang terjadi karena beda pendapat. Jadi dapat disimpulkan komite audit tidak berpengaruh terhadap tax avoidance.

\section{Laporan Keuangan \\ Pengaruh arus kas operasi terhadap tax avoidance}

Berdasarkan hasil pengujian yang dilakukan menunjukkan bahwa arus kas operasi berpengaruh terhadap tax avoidance. Penelitian ini sejalan dengan penelitian yang dilakukan oleh (Kim \& Im, 2017) mengatakan bahwa arus kas operasi berpengaruh terhadap tax avoidance.

Hasil dari penelitian ini menyatakan bahwa arus kas operasi berpengaruh terhadap tax avoidance. Aktivitas operasi sebagai penentu besar kecilnya laba/rugi bersih perusahaan. Apabila kas dari penjualan barang atau jasa meningkat maka beban pajak perusahaan juga meningkat, sehingga perusahaan menekan beban pajak agar beban pajak yang ditangguhkan pada perusahaan lebih rendah. Jadi dalam hal ini perusahaan cenderug melakukan tax avoidance yaitu dengan cara menekan beban pajak agar laba yang diperoleh perusahaan tetap tinggi.

\section{SIMPULAN}

Penelitian ini menggunakan variabel dependen yaitu tax avoidance dan variabel independen yang digunakan dalam penelitian ini yaitu ukuran perusahaan, leverage, profitabilitas, pertumbuhan penjualan, komite audit dan arus kas operasi. Tujuan dalam penelitian ini yaitu untuk mengetahui pengaruh ukuran perusahaan, leverage, profitabilitas, pertumbuhan penjualan, komite audit dan arus kas operasi terhadap tax avoidance. Penelitian ini difokuskan pada perusahaan LQ45 Yang Terdaftar Di Bursa Efek Indonesia Tahun 2015-2018. Pengambilan sampel menggunakan purposive sampling yang menghasilkan 51 sampel. Alat analisis yang digunakan dalam penelitian ini menggunakan regresi linear berganda. Hasil dari penelitian ini variabel arus kas operasi berpegaruh terhadap tax avoidance. Variabel ukuran perusahaan, leverage, profitabilitas, pertumbuhan penjualan dan komite audit tidak berpengaruh terhadap tax avoidance.

\section{DAFTAR PUSTAKA}

Almaidah, M., Titisari, K. H., \& Nurlaela, S. (2017). Pengaruh Karakteristik Perusahaan, Sales Growth dan CSR Terhadap Tax Avoidance. Seminar Nasional IENACO-2017, ISSN: 2337-4349.

Andayani, R. D., \& Wirajaya, I. G. (2015). kemampuan laba, arus kas operasidalam memprediksi arus kas masa depan. E-jurnal Akuntansi Universitas Udayana, ISSN : 2302-8556.
Anouar, D., \& Houria, Z. (2017). The Determinants Of Tax Avoidance Within Corporate Groups: Evidence From Moroccan Groups. International Journal Of Economics, Finance and Management Groups, ISSN: 2326-9561.

Ardianti, P. (2019). Profitabilitas, Leverage, dan Komite Audit Pada Tax Avoidance. E-Jurnal Akuntansi Universitas Udayana, ISSN: 2302-8556.

Arianandini, P. W., \& Ramantha, I. W. (2018). Pengaruh Profitabilitas, Leverage, dan Kepemilikan Institusional pada Tax Avoidance. E-Jurnal Akuntansi Universitas Udayana, ISSN: 23028556.

Asri, I., \& Suardana, K. A. (2016). Pengaruh Proporsi Komisaris Independen, Komite Audit, Preferensi Risiko Eksekutif dan Ukuran Perusahaan Pada Penghindaran Pajak. E-Jurnal Akuntansi Universitas Udayana, ISSN: 2302-8556, 72-100.

Dewi, N. P., \& Noviari, N. (2017). Pengaruh Ukuran Perusahaan, Leverage, Profitabilitas, dan Corporate Social Responsibility Terhadap Penghindaran Pajak (Tax Avoidance). E-Jurnal Akutansi Universitas Udayana, ISSN: 2302-8556.

Dewinta, I., \& Setiawan, P. E. (2016). Pengaruh Ukuran Perusahaan, Umur Perusahaan, Profitabilitas, Leverage dan Pertumbuhan Penjualan Terhadap Tax Avoidance. E-Jurnal Akuntansi Universitas Udayana, ISSN: 2302-8556.

Kim, J. H., \& Im, C. C. (2017). The Study On The Effect And Determinants Of Small- And Medium- Sized Entities Conducting Tax avoidance. The Journal Of Applied Business Research - March/April 2017, Volume 33, Number 2.

kusufiyah, Y. V., \& Anggraini, D. (2019). Peran Komisaris Independen, Ukuran Perusahaan, Kinerja Keuangan dan Leverage Terhadap Usaha Penghindaran Pajak. E-Jurnal Akuntansi Universitas Udayana, ISSN: 2302-8556.

Mulyani, S., Wijayanti, A., \& Masitoh, E. (2018). Pengaruh Corporate Governance Terhadap Tax Avoidance. Jurnal Riset Akuntansi dan Bisnis Airlangga Vol.3 No.1 2018, ISSN: 2548-4346.

Nugraheni, A. S., \& Pratomo, D. (2018). Pengaruh komite audit, kualitas audit, dan ukuran audit terhadap tax avoidance. . e-Proceeding of Management, ISSN : 2355-9357.

Oktamawati, M. (2017). Pengaruh Karakter Eksekutif, Komite Audit, Ukuran Perusahaan, Leverage, Pertumbuhan Penjualan, dan Profitabilitas Terhadap Tax Avoidance. Jurnal Akuntansi Bisnis, ISSN: 2541-5204.

Permata, A. D., Nurlaela, S., \& Masitoh, E. (2018). Pengaruh size, age, profitability, leverage, dan sales groeth terhadap tax avoidance. Jurnal Akuntansi Pajak, ISSN : 2579-3055.

Praditasari, N., \& Setiawan, P. E. (2017). Pengaruh Good Corporate Governance, Ukuran Perusahaan, 
Leverage,dan Profitabilitas Pada Tax Avoidance. E-Jurnal Akuntansi Universitas Udayana, ISSN: 2302-2556.

Putri, R. D. (2018). Pengaruh Corporate Governance Terhadap Tax Avoidance ( Studi Empiris Perusahaan Sektor Perbankan Yang Terdaftar Di BEI Tahun 2012-2016 ). Jurnal Ekonomi dan Bisnis Dharma Andalas Volume 20 No 2, Juli 2018, ISSN: 2527- 3469. 